\title{
Breakdown of mantle metasomatic phases and implications for primary basalt compositions in intraplate volcanic provinces
}

\author{
Brenna M. 1, Pontesilli A. 1, PAlin J.M. 1 , Pilet S.2 \\ 1 University of Otago, 360 Leith St. Dunedin 9016 (NZ) \\ (corresponding: marco.brenna@otago.ac.nz) \\ 2 University of Lausanne, CH 1015 Lausanne (Switzerland)
}

Intraplate alkaline provinces, particularly those forming fields of small volcanoes, often display a range in basaltic composition spanning the alkaline to subalkaline spectrum. Traditional geochemical models justify the range by various degrees of partial melting of mantle peridotite as well as involvement of heterogeneous source lithologies. Alternative scenarios involve stepwise interaction and metasomatism of the lithospheric mantle by asthenosphere-derived silicate fluids and subsequent metasome melting to form alkaline to subalkaline primary magmas. The Auckland Volcanic Field is a unique case study to unravel the "primary magma conundrum" because of the detailed knowledge of products from its $\sim 50$ eruptions and occurrence of mantle xenoliths. Here we present the first microchemical investigation of mantle peridotite xenoliths from the Auckland Volcanic Field with the aim of understanding metasomatic modification of the lithospheric mantle. Xenoliths consist of lherzolite, harzburghite and dunite with occurrence of rare $\mathrm{Cr}$ - and $\mathrm{Na}$ rich diopside and phlogopite. These phases show sieve/breakdown textures and are surrounded by vesiculated glass with trachytic composition that extends into the surrounding peridotite. Glass associated with diopside is characterized by HFSE depletion, $\mathrm{Th}, \mathrm{Pb}$ and $\mathrm{Sr}$ enrichment and concave up MREE to HREE patterns. Glass surrounding phlogopite has $\mathrm{Rb}, \mathrm{Nb}, \mathrm{Ta}, \mathrm{K}, \mathrm{Pb}, \mathrm{Zr}$ and $\mathrm{Hf}$ enrichment and variable Th, U, La and Ce depletion. Mineral compositions mirror those of their surrounding glass implying their partial melting rather than infiltration of host melt. Short diffusion profiles into surrounding peridotite phases indicate that breakdown occurred as a result of entrainment in the host basalt. Mineral and glass characteristics record involvement of different metasomatic fluids. Diopside likely formed from percolation of subduction derived fluids with potentially a carbonatitic component and may be a late stage percolative fractionate after amphibole vein formation. Metasomatic phlogopite formed in response to percolation of asthenospheric OIB-like silicate fluids. The mantle beneath Auckland has experienced several episodes of metasomatic modification that likely impacted the alkaline-subalkaline specturm of erupted lavas. 